\title{
PEMBERDAYAAN MASYARAKAT DESA DALAM BIDANG INDUSTRI, PENDIDIKAN DAN KESEHATAN GUNA MENDUKUNG PROGRAM DESA SEJAHTERA MANDIRI
}

\author{
Dini Sri Damayanti' ${ }^{1}$ Eka Dewi Mayasari ${ }^{1}$, Rucitra Sectio Prasetya Putri², Adji Surya \\ Hutama $^{3}$, Dana Sefrina Sulviadi ${ }^{3}$, Ilham Ramadhan', Bagas Sedyarsa Utama ${ }^{3}$, Elviani \\ Nuril Laily ${ }^{2}$, Ivan Hartaji ${ }^{2}$, Ayudya Nurhaliza Zuhro ${ }^{2}$ \\ ${ }^{1}$ Fakultas Kedokteran, Universitas Islam Malang \\ ${ }^{2}$ Fakultas Keguruan dan Ilmu Pendidikan, Universitas Islam Malang \\ ${ }^{3}$ Fakultas Ekonomi dan Bisnis, Universitas Islam Malang \\ ${ }^{4}$ Fakultas Teknik, Universitas Islam Malang
}

Korespondensi email: dinisridamayanti@gmail.com

\begin{abstract}
ABSTRAK
Desa Sukodono Kecamatan Dampit Kabupaten Malang merupakan salah satu daerah tujuan KKN Universitas Islam pada periode Pebruari 2020. Tujuan Kegiatan pengabdian kepada masyarakat (PPM) dalam rangka kegiatan KKN yang dilakukan oleh kelompok 63 adalah (1) Meningkatkan perekonomian masyarakat di Desa Sukodono dengan cara pembuatan produk olahan selai kopi, (2) Meningkatkan movitasi belajar siswa di SDN 1 Sukodono, dan (3) Meningkatkan tindakan preventif dan promotif stunting di Desa Sukodono. Kegiatan dilakukan melalui metode penyuluhan dan pelatihan, diskusi dan tanya jawab, serta demonstrasi secara langsung. Hasil akhir dari kegiatan menunjukkan bahwa kegiatan pengabdian kepada masyarakat (PPM) mampu memberikan motivasi dan perubahan pola fikir kepada masyarakat di Desa Sukodono terutama tentang bagaimana cara membuat produk olahan dari serbuk kopi, meningkatkan motivasi belajar siswa dan meningkatkan tindakan preventif dan promotif stunting. Kendala-kendala yang muncul dapat diatasi dengan metode pelatihan secara bertahap. Adanya MOU kerjasama dengan pemerintah daerah dan pemerintah desa perlu dilakukan untuk keberlajutan program secara kontinue dan dievaluasi keberhasilannya dalam meningkatkan ekonomi, kesejahteraan dan penurunan angka stunting di Kabupaten Malang.
\end{abstract}

Kata Kunci: produk olahan; motivasi belajar; sukodono; stunting.

\section{PENDAHULUAN}

Selai merupakan produk pangan olahan yang berbahan dasar buah yang bisa merupakan buah utuh, bagian dari buah maupun bubur buah dengan atau tanpa penambahan konsentrat buah atau sari buah yang dicampur dengan bahan pemanis, dengan atau tanpa penambahan air yang diproses hingga diperoleh konsistensi yang sesuai (FAO, 2009). Menurut Food and Agriculture Organization (FAO) kriteria selai yang sesuai standar adalah memiliki konsistensi gel yang baik, memiliki warna dan flavouryang sesuai dengan buah yang digunakan, dan harus bebas dari cemaran fisik seperti kulit buah, batu, dan pasir. Secara umum buah yang digunakan untuk membuat selai adalah buah yang kaya akan pektin, namun buah yang memiliki kandungan pektin rendah juga bisa dibuat menjadi selai dengan penambahan pektin atau bahan pembentuk gel lainnya (Linggawati, 2017). 
Kopi adalah salah satu bahan selain buah yang dapat digunakan sebagai bahan untuk membuat selai. Kopi merupakan salah satu sumber pendapatan negara Indonesia. Produksi kopi di Indonesia terus mengalami peningkatan dari tahun ke tahun (Marhaenanto et al., 2015). Pada tahun 1980 produksi kopi di Indonesia sebesar 294.793 ton dan terus meningkat hingga 639.305 ton pada tahun 2016. Namun, sebagian besar produksi kopi di Indonesia adalah untuk diekspor. Volume biji kopi yang diekspor pada bulan September 2016 adalah sebesar 267.058 ton, yaitu sekitar 40\% dari total produksi kopi (Kustiari, 2016; Sahat et al., 2016).

Menurut data yang diperoleh dari profil Desa tahun 2018, di desa Sukodono mayoritas masyarakatnya $90 \%$ bekerja sebagai petani dan sebagian besar lahan di desa tersebut ditanami oleh kopi. Melihat adanya potensi untuk meningkatkan perekonomian warga dengan menggunakan produk olahan kopi maka timbul suatu gagasan membuat produk olahan baru berupa selai kopi (Jufriyanto, 2019).

Motivasi belajar merupakan salah satu faktor yang turut menentukan keefektifan dalam pembelajaran. Seorang peserta didik akan belajar dengan baik apabila ada faktor pendorongnya yaitu motivasi belajar (Kurniasih et al., 2019). Peserta didik akan belajar dengan sungguh-sungguh jika memiliki motivasi belajar yang tinggi. Motivasi belajar adalah seluruh daya penggerak didalam diri siswa yang menimbulkan kegiatan belajar yang menjamin kelangsungan dari kegiatan belajar yang memberikan arah pada kegiatan belajar sehingga tujuan yang dikehendaki oleh subjek belajar itu dapat dicapai (Pahenra et al., 2017; Ulia et al., 2019).

Ada banyak faktor yang mempengaruhi motivasi belajar yang dapat dibedakan menjadi dua faktor. Menurut Rohman \& Karimah (2018) motivasi belajar dapat timbul karena faktor internal dan eksternal. Faktor Internal yang mempengaruhi motivasi belajar yaitu: (1) Faktor Fisik meliputi nutrisi (gisi), kesehatan, dan fungsi-fungsi fisik (terutama panca indera), (2) Faktor Psikologis, yaitu berhubungan dengan aspek-aspek yang mendorong atau menghambat aktivitas belajar pada siswa. Faktor eksternal (yang berasal dari lingkungan) yang mempengaruhi motivasi belajar meliputi: (1) Faktor Non-Sosial meliputi keadaan udara (cuaca panas atau dingin), waktu (pagi, siang, malam), tempat (sepi, bising, atau kualitas sekolah tempat belajar), sarana dan prasarana belajar, (2) Faktor Sosial, merupakan faktor manusia (guru, konselor, dan orang tua).

Sehubungan dengan faktor-faktor tersebut, pengajar sangat berperan dalam meningkatkan motivasi belajar(Arifin \& Tamrin, 2019). Karena dari hasil pengamatan pada SDN 1 Sukodono Kecamatan Dampit bahwa pada saat kegiatan pembelajaran berlangsung ada sekitar 4 orang siswa tidak memperhatikan dan ribut sendiri didalam kelas untuk itu peningkatan motivasi siswa di SDN 1 Sukodono perlu dilakukan.

Stunting atau perawakan pendek (shortness) merupakan suatu keadaan tinggi badan (TB) seseorang yang tidak sesuai dengan umur, yang penentuannya dilakukan dengan menghitung skor Z-indeks Tinggi Badan menurut Umur (TB/U). Seseorang dikatakan stunting bila skor Z-indeks TB/U- nya di bawah -2 SD (standar deviasi). Riset Kesehatan Dasar 2013 mencatat prevalensi stunting nasional mencapai 37,2 \%, meningkat dari tahun 2010 (35,6\%) dan 2007 (36,8\%). Artinya, pertumbuhan tidak maksimal diderita oleh sekitar 8,9 juta anak Indonesia, atau satu dari tiga anak Indonesia. Indonesia menduduki peringkat kelima dunia untuk jumlah anak dengan kondisi stunting. Lebih dari sepertiga anak berusia di bawah lima tahun di Indonesia tingginya berada di bawah ratarata (Kartini et al., 2016; Sutarto et al., 2019).

Catatan di Dinas Kesehatan (Dinkes) Kabupaten Malang pada Februari 2019 lalu menyebut bila jumlah anak yang stunting tersisa di angka 16,1\% dari total 145.202 balita. Tercatat 10 desa dengan jumlah terbanyak anak stunting. Di antaranya, Desa Wonorejo, 
Kecamatan Bantur; Desa Tambakrejo, Kecamatan Sumbermanjing Wetan; Desa Baturetno, Kecamatan Dampit; dan Desa Mulyosari, Kecamatan Ampelgading Desa Wonoayu, Kecamatan Wajak; Desa Purwosekar, Kecamatan Tajinan; Desa Pujon Kidul, Kecamatan Pujon; Desa Pait, Kecamatan Kasembon; dan Desa Brongkal Kecamatan Pagelaran.

Data yang didapat dari Laporan Konvergensi Pencegahan Stunting tingkat Desa terhadap sasaran rumah tangga 1000 HPK Kecamatan Dampit Desa Sukodono pada bulan Januari 2020 didapatkan jumlah total ibu hamil resiko KEK / resiko tinggi sebanyak 2/13, jumlah anak terindikasi stunting 11 orang, jumlah anak beriesiko stunting 19 orang, Kunjungan ibu hamil K1-K4 sekitar 46\%, ibu hamil yang mendapat tablet FE minimal 90 hari 46\%, ibu hamil mengikuti konseling gizi 46\%, akses air minum yang bersih 46\%, RT ibu hamil yang memiliki jamban 46\%, serta jumlah tenaga kesehatan desa sebanyak 2 orang (1 bidan dan 1 perawat) serta 32 kader kesehatan.

Berbagai permasalahan tersebut tentunya sangat disayangkan oleh karena itu sudah sepatutnya permasalahan tersebut harus diangkat dan diselesaikan dengan menggunakan metode penyuluhan, diskusi, tanya jawab, dan juga demonstrasi secara langsung kepada masyarakat.

\section{METODE}

Pelatihan yang diangkat dalam kegiatan pengabdian kepada masyarakat ini bertujuan untuk meningkatkan perekonomian masyarakat di Desa Sukodono dengan cara produk pengolahan baru, meningkatkan movitasi belajar siswa di SDN 1 Sukodono dan meningkatkan tindakan preventif dan promotif stunting di Desa Sukodono. Sasaran pada pengabdian masyarakat ini adalah warga Desa Sukodono, siswa di SDN 1 Sukodono dan kader kesehatan di Desa Sukodono. Metode pelatihan yang digunakan untuk mendukung keberhasilan program ini antara lain sebagai berikut:

1. Penyuluhan, diskusi dan tanya jawab

Metode ini dipilih untuk meningkatkan pengetahuan masyarakat dan juga untuk lebih memahami tentang apa dan bagaimana program itu berlangsung.

2. Demontrasi

Metode ini dipilih untuk menjelaskan suatu proses kerja secara bertahap sehingga memberikan kemudahan untuk masyarakat.

Untuk mengetahui keberhasilan dari kegiatan ini dapat dilakukan dengan melihat keterlibatan masyarakat dan juga antusias dari masyarakat. Keterlibatan peserta dapat dilihat dari kehadiran peserta dan antusiasme peserta dapat dilihat dari motivasi peserta selama kegiatan berlangsung.

\section{HASIL DAN PEMBAHASAN}

Pada kegiatan pelaksanaan program yang pertama adalah pembuatan selai kopi sebagai produk olahan terbaru. Kegiatan ini memakan waktu sekitar 3 minggu mulai dari proses pembelian bahan baku, proses pembuatan contoh produk, proses penyluhan dan pelatihan. Alasan menciptakan produk selai kopi sebagai produk olahan baru karena Desa Sukodono merupakan salah satu desa penghasil kopi pilihan di Kabupaten Malang. Selain itu produk olahan tersebut belum pernah di produksi oleh masyarakat desa Sukodono.

Penyuluhan dan pelatihan dilakukan pada ibu-ibu PKK Desa Sukodono yang bertempat di TK Muslimat Sunan Kalijogo. Dalam kegiatan penyuluhan dan pelatihan pembuatan produk tersebut tim KKN 63 menjelaskan tentang peluang bisnis dari produk selai kopi serta menjelaskan dan mendemonstrasikan bagaimana membuat selai kopi yang mudah dan praktis. Cara pembuatan selai kopi yaitu dengan memasukkan terlebih dahulu 2 sendok makan bubuk kopi, 1 gelas susu kental manis, dan 3 sendok makan gula pasirg 
kedalam air mendidih 150 cc. Campuran diaduk hingga merata dan sedikit mengental diatas api kecil, lalu ditambahkan 3 sendok makan tepung terigu yang telah dilarutkan didalam air, dan terakhir memasukkan 1 sendok makan mentega, kemudian kembali diaduk hingga benar-benar mengental. Setelah selesai, proses terakhir adalah menuangkan selai kopi kedalam wadah kecil yang sebelumnya sudah didinginkan. Kelemahan dari kegiatan ini, kami belum sempat memberikan cara pengemasan dan labeling serta cara pengurusan ijin produksi sehingga produk olahan kopi yang telah kami sosialisasikan bisa segera dapat menjadi produk olahan yang siap jual.

Pemasaran produk merupakan salah satu kendala bagi perkembangan produk olahan baru. Oleh sebab itu perlu adanya kegiatan promosi terkait produk yang dhasilkan kepada masyarakat. Promosi sederhana dari mulut ke mulut dianggap kurang efektif, sehingga pelu tindakan lain untuk promisi. Salah satu faktor penting dari promosi adalah labeling dan pengemasan produk. Proses pembuatan labeling dan pengemasan produk ini membutuhkan pendampingan untuk membuat label produk sesuai dengan keinginan produsen. Hal ini perlu dilakukan karena labeling dan pengemasan sangat memengaruhi daya beli konsumen terhadap suatu produk (Setyawan \& Sari, 2016; Kurniawati et al., 2019).

Pelaksanaan kegiatan membantu proses pembelajaran di SDN 1 Sukodono, dilaksanakan pada minggu pertama hingga minggu terakhir kegiatan progam KKN. Proses mengajar dilaksanakan setiap hari Senin sampai Sabtu, jam 08.00 sampai - 12.00. Proses mengajar dilakukan dengan cara membuat permainan yang diselingi materi pelajaran yang sudah diajarkan. Selain itu, proses pembelajaran juga dilakukan dengan menggunakan teknologi modern seperti ponsel saat menerangkan materi pelajaran, dengan begitu siswa di SDN 1 Sukodono bisa belajar sambil bermain, serta tidak mudah bosan saat proses pembelajaran berlangsung. Selain itu disela-sela proses belajar kami juga mengajak mereka untuk berdikusi dan juga menanamkan motivasi belajar yang kuat kepada mereka supaya kedepannya mereka tetap bersemangat untuk belajar.

Guru merupakan motivator dalam rangka meningkatkan semangat belajar siswa dan pengembangan kegiatan belajar siswa. Dengan adanya motivasi maka siswa akan mempersiapkan dirinya dalam proses belajar mengajar. Menurut Emda (2017) motivasi merupakan salah satu prasarat yang paling penting dalam belajar. Bila tidak ada motivasi, proses belajar tidak akan terjadi, karena motivasi dapat mempengaruhi proses dan hasil belajarpun jasmani.

Motivasi merupakan dorongan yang timbul pada diri seseorang secara sadar atau tidak sadar untuk melakukan suatu tindakan dengan tujuan tertentu. Motivasi terbagi menjadi motivasi intrinsik dan ekstrinsik. Motivasi intrinsik merupakan dorongan yang timbul dari dalam individu untuk berbuat sesuatu. Adapun motivasi ekstrinsik merupakan dorongan yang timbulnya dari luar individu. Dalam proses belajar, motivasi mempunyai peranan yang sangat penting untuk membangkitkan semangat belajar siswa. Motivasi belajar dapat dilihat dari karakter tingkah laku siswa yang menyangkut minat, ketajaman perhatian, konsentrasi dan tekun mencapai tujuan (Pahenra et al., 2017).

Penyuluhan Kesehatan Deteksi Dini Stunting dan Ibu Hamil Resiko tinggi, pelatihan Kader Kesehatan dan Pengobatan Gratis yang diadakan di desa Sukodono Kecamatan Dampit, Kabupaten Malang pada hari Kamis tanggal 27 Pebruari 2020. Kegiatan tersebut bekerjasama dengan FK UNISMA. Tujuan pelaksanaan kegiaan tersebut adalah untuk memberikan informasi dan meningkatkan pengetahuan ibu-ibu dengan anak balita, calon ibu dan ibu hamil mengenai ciri-ciri stunting, dampak stunting, dan pencegahan terjadinya stunting. Disamping itu pelatihan kepada kader untuk detekdi dini stunting pada balita dilakukanuntuk proses penyegaran dan panambahan wawasan ilmu tentang stunting. 
Data kesehatan di desa Sukodono dijumpai penderita stunting, walaupun jumlahnya tidak terlalu banyak, sekitar 9 orang (data tahun 2019). Namun ada kecenderungan terjadi peningkatan jumlah penderita stunting di tahun 2020 (Pebruari 2020 menjadi 11 orang).

Stunting atau perawakan pendek merupakan salah satu masalah gizi kronis yang ditandai dengan tinggi badan yang tidak sesuai dengan umur. Penentuan dilakukan dengan menghitung skor Z-indeks. Dikatakan stunting bila skor Z-indeks TB/U- nya di bawah -2 SD (standar deviasi). Indonesia masuk dalam urutan kelima di dunia dengan jumlah penderita stunting terbanyak di Asia Tenggara. Adapun dampak dari stunting adalah ukuran tubuh pendek, mudah mengalami infeksi, pertumbuhan dan perkembangan otak terganggu, sehingga kesemua akan menurunkan kualitas dari SDM bangsa di masa depan.

Faktor-faktor yang dikaitkan dengan meningkatnya jumlah penderita stunting di Indonesia adalah: kurangnya pengetahuan ibu mengenai gizi saat sebelum hamil, saat hamil dan periode menyusui, ibu mengalami kekurangan gizi saat sebelum hamil, saat hamil dan saat menyusui, tidak melakukan ASI eksklusif, terlalu muda melahirkan, terlalu banyak anak, terlalu sering melahirkan, kondisi ekomoni keluarga yang kurang, sanitasi lingkungan yang buruk.

Kegiatan penyuluhan deteksi dini dan pencegahan stunting bertujuan untuk memotong rantai peningkatan jumlah pasien stunting melalui peningkatan pengetahuan masayarakat dan kader kesehatan mengenati stunting. Dengan demikian diharapkan berdampak pada penurunan jumlah penderita stunting, yang secara tidak langsung akan meningkatkan kualitas SDM bangsa Indonesia di masa depan. Kelemahan dari kegiatan penyuluhan dan pelatihan kepada masyarakat dan kader hanya dilaksanakan dalam satu kali pelaksanaan. Hal ini menyebabkan tidak bisa mengevalusi keberhasilan program yang telah dilaksanakan. Perlu adanya kerjasama dengan pemda Kabupaten Malang dan pemerintah desa Sukodono untuk melanjutkan kegiatan secara continue dan berkelanjutan serta bekerjasama dengan lintas sektoral dan komponen masyarakat desa Sukodono sehingga didapatkan hasil yang optimal menurunkan jumlah penderita stunting di desa Sukodono khususnya dan Kabupaten Malang pada umumnya.

\section{KESIMPULAN}

Adapun kesimpulan yang dapat ditarik setelah dilakukannya kegiatan pengabdian kepada masyarakat (PPM) ini adalah:

1. Kegiatan program pengabdian kepada masyarakat (PPM) yang diselenggarakan mampu membuat perubabahan pola hidup kepada masyarakat.

2. Kegiatan program pengabdian kepada masyarakat (PPM) yang telah diselenggarakan dapat meningkatkan pengetahuan masyarakat.

3. Kegiatan program pengabdian kepada masyarakat (PPM) yang telah diselenggarakan mampu untuk meningkatkan kreatifitas masyarakat.

Adanya keberlanjutan program Pengabdian Masyarakat yang dilakukan oleh Universitas Islam Malang untuk proses:

1. Pendampingan ibu-ibu PKK dalam proses pengemasan dan labeling produksi olahan untuk meningkatkan daya jual produk.

2. Keberlajutan kegiatan pencegahan stunting dengan melibat PEMDA dan Pemerintah Desa Sukodono serta lintas sektoral dan Universitas Islam Malang untuk menurunkan jumlah penderita stunting di Kabupaten Malang dan desa Sukodono Khususnya.

\section{DAFTAR RUJUKAN}

Arifin, Z., \& Tamrin, T. (2019). Peningkatan Kompetensi Microcontroller Siswa SMK. Jurnal Inovasi Hasil Pengabdian Masyarakat (JIPEMAS), 2(1), 49-53. 
https://doi.org/10.33474/jipemas.v2i1.1772

Emda, A. (2017). Kedudukan Motivasi Belajar Siswa Dalam Pembelajaran. Lantanida Journal, 5(2), 172-182. https://doi.org/10.22373/lj.v5i2.2838

Jufriyanto, M. (2019). Pengembangan Produk Unggulan Sebagai Potensi Peningkatan Ekonomi Masyarakat Desa di Kecamatan Modung Bangkalan. Jurnal Ilmiah Pangabdhi, 5(1), 28-32. https://doi.org/10.21107/pangabdhi.v5i1.5162

Kartini, A., Suhartono, Subagio, H. W., Budiyono, \& Emman, I. M. (2016). Kejadian Stunting Dan Kematangan Usia Tulang Pada Anak Usia Sekolah Dasar Di Daerah Pertanian Kabupaten Brebes. Jurnal Kesehatan Masyarakat, 11(2), 96-103. https://doi.org/10.15294/kemas.v11i2.4271

Kurniasih, Rahmati, N. A., Umamah, A., \& Widowati, D. R. (2019). English Conversation Class (ECC) Untuk Menciptakan English Environment Di SMA Islam Nusantara (SMAINUS). Jurnal Inovasi Hasil Pengabdian Masyarakat (JIPEMAS), 2(2), 161-169. https://doi.org/10.33474/jipemas.v2i2.2571

Kurniawati, E., Santoso, A., \& Widowati, S. Y. (2019). Pelatihan Pemasaran Online Bagi Kelompok Usaha Bersama (KUB) "SRIKANDI". Jurnal Inovasi Hasil Pengabdian Masyarakat (JIPEMAS), 2(2), 132-138. https://doi.org/10.33474/jipemas.v2i2.2722

Kustiari, R. (2016). Perkembangan Pasar Kopi Dunia dan Implikasinya bagi Indonesia. $\begin{array}{lllll}\text { Forum Penelitian Agro } & \end{array}$ https://doi.org/10.21082/fae.v25n1.2007.43-55

Marhaenanto, B., Soedibyo, D. W., \& Farid, M. (2015). Penentuan lama Sangrai Kopi Terhadap Variasi Derajat Sangrai Menggunakan Model Warna Rgb Pada Pengolahan Citra Digital (Digital Image Processing). Jurnal Agroteknologi, 09(02), 1-10. https://jurnal.unej.ac.id/index.php/JAGT/article/view/3536

Pahenra, Arfin, \& Reni. (2017). Hubungan Pola Interaksi Sosial Dengan Motivasi Belajar Siswa. Pendidikan Dan Ilmu Pengetahuan, 17(1), 64-80. https://doi.org/10.30651/didaktis.v17i1.1557

Rohman, A. A., \& Karimah, S. (2018). Faktor-Faktor Yang Mempengaruhi Rendahnya Motivasi Belajar Siswa Kelas XI. Jurnal At-Taqaddum, 10(1), 95-108. https://doi.org/10.21580/at.v10i1.2651

Sahat, S. F., Nuryartono, N., \& Hutagaol, M. P. (2016). Analisis Pengembangan Ekspor Kopi Di Indonesia. Jurnal Ekonomi Dan Kebijakan Pembangunan, 5(1), 63-89. https://doi.org/10.29244/jekp.5.1.63-89

Setyawan, F., \& Sari, P. N. (2016). Labelling Kemasan Sebagai Upaya Pengembangan Pemasaran Agroindustri Emping Jagung di Desa Tirtomulyo, Kretek, Bantul. Jurnal Pengabdian Kepada Masyarakat (Indonesian Journal of Community Engagement), 1(2), 231-238. https://doi.org/10.22146/jpkm.10609

Sutarto, Sumekar, D. W., Wijaya, S. M., \& Indriyani, R. (2019). Permodelan Probabilitas Kejadian Stunting. Jurnal Kedokteran Universitas Lampung (JK Unila), 3(1), 16-20.

Ulia, N., Ismiyanti, Y., \& Setiana, L. N. (2019). Meningkatkan Literasi Melalui Bahan Ajar Tematik Saintifik Berbasis Kearifan Lokal. Jurnal Inovasi Hasil Pengabdian Masyarakat (JIPEMAS), 2(2), 150-160. https://doi.org/10.33474/jipemas.v2i2.3402 